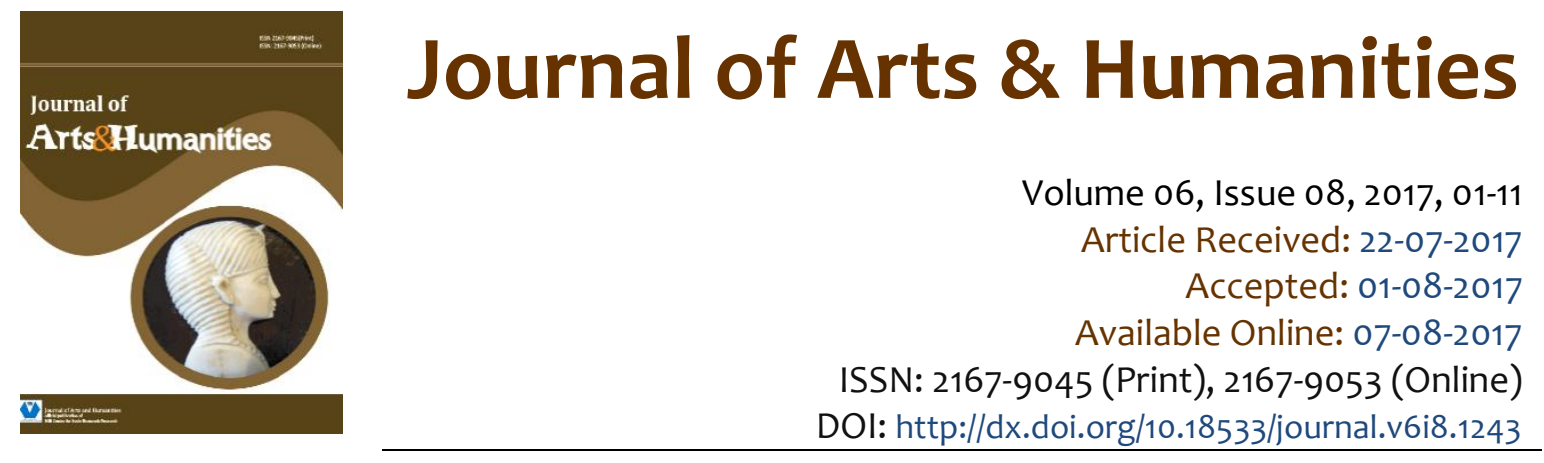

\title{
Framing Gangnam Style
}

\author{
Hyunsun Catherine Yoon', Sae Kyung $\mathrm{Yu}^{2}$, Seung Hee $\mathrm{Yoo}^{3}$
}

\begin{abstract}
This paper examines the way in which news about Gangnam Style was framed in the Korean press. First released on 15th July 2012, it became the first video to pass two billion views on YouTube. 400 news articles between July 2012 and March 2013 from two South Korean newspapers - Chosun Ilbo and Hankyoreh were analyzed using the frame analysis method in five categories: industry/economy, globalization, cultural interest, criticism, and competition. The right-left opinion cleavage is important because news frames interact with official discourses, audience frames and prior knowledge which consequently mediate effects on public opinion, policy debates, social movement and individual interpretations. Whilst the existing literature on Gangnam Style took rather holistic approach, this study aimed to fill the lacuna, considering this phenomenon as a dynamic process, by segmenting different stages - recognition, spread, peak and continuation. Both newspapers acknowledged Gangnam Style was an epochal event but their perspectives and news frames were different; globalization frame was most frequently used in Chosun Ilbo whereas cultural interest frame was most often used in Hankyoreh. Although more critical approaches were found in Hankyoreh, reflecting the right-left opinion cleavage, both papers lacked in critical appraisal and analysis of Gangnam Style's reception in a broader context of the new Korean Wave.
\end{abstract}

Keywords: Frame Analysis, Gangnam Style, Korean Wave, News Frame, Popular Music, Psy.

This is an open access article under Creative Commons Attribution 4.0 License.

\section{Introduction}

First released on $15^{\text {th }}$ July 2012, Psy's Gangnam Style became the first video to pass two billion views on Youtube (BBC News, May 31, 2014). A great deal of media attention has been paid to this song and its 'horse dance', which also relates to the popularity of the Korean popular culture (the Korean wave; hanryu), in particular the rise of K-pop since late 2000s. Many have argued that the nationalistic approaches used in the media coverage of the Korean wave could in fact become the barriers of its

\footnotetext{
1 Senior Lecturer, School of Arts and Digital Industries, University of East London, United Kingdom. Email: hyunsun_yoon@yahoo.co.uk

2 Professor, Department of Media Studies, College of Social Science, Ewha Womans University, Korea. Email: sgyu@ewha.ac.kr

3 Department of Media Studies, College of Social Science, Ewha Womans University, Korea. Email: yooseunghee1107@gmail.com
} 
own success worldwide in the long term (Yoon 2002; Kim, Lee and Lee 2005; Choi and Ryoo 2012; Joo 2012). In a similar vein, a pop-nationalistic approach to Psy's success was critiqued (Ko 2012). Although more investigative, in-depth, analytical approaches to understand the fandom and reception of Gangnam Style have been called for (KBS, November 2, 2012), few studies have so far looked at the news framing of Gangnam Style in different stages in the development of its fandom. The aim of this is therefore to fill this lacuna by investigating the prevalent news frames in the news coverage of Gangnam Style in the two major daily newspapers - Chosun Ilbo and Hankyoreh - between July 2012 and March 2013. This period is further broken down to four stages: recognition, spread, peak and continuation period. By doing so, it sets out to compare and contrast the similarities and differences between the two papers in terms of the ways in which the news was framed, depending on the timing of the news and the type of the newspaper.

News media has the agenda setting role in society, which influences the ways in which the public understands certain issues. In addition, news media can have different perspectives on the same issue or event depending on their own organizational interests, values and ideologies. One influential way that the news media may shape public opinion is by framing events and issues in particular ways and frames in the news may affect learning, interpretation, and evaluation of issues and events (De Vreese 2005: 51-52). By comparing the news frames used in reporting Gangnam Style in two daily newspapers with clear right-left opinion cleavage, this paper examined the similarities and differences in the news framing and its implications. The findings indicated that both newspapers acknowledged Gangnam Style was an epochal event but their perspectives and news frames were different; globalization frame was most frequently used in Chosun llbo whereas cultural interest frame was most often used in Hankyoreh. Although more critical approaches were found in Hankyoreh, reflecting the right-left opinion cleavage, both papers lacked in critical appraisal and analysis of Gangnam Style's reception in a broader context of the new Korean Wave. The contribution of this paper in the literature is two-fold: first, it provides a wealth of empirical data on the prevalent news frames used to cover the so called Gangnam Style phenomenon; and second, it updates the application of the news frame analysis to the study of contemporary popular music and its fandom by establishing the authors' own analytical framework adopted from Semetko and Valkenburg (2000).

The rest of this paper has the literature review, research design and methodology, findings and discussions and conclusion.

\section{Literature review}

In this section, the existing literature on Gangnam Style and the news framing is discussed. It would be fair to say that Gangnam Style had the phenomenal success in many parts of the world. A possible exception to this was Japan (Lie 2013). Lie (2013: 44) argued that due to the involuted nature of the Japanese popular music industry, especially the imperative of indigenization, Gangnam Style failed to go viral in Japan and to resonate with its potential base of Japanese K-pop fans who valorized beauty and romance. This finding was interesting and yet somewhat expected given the mood of the anti-Korean wave or hate-Korean wave in Japan since mid-2000s (see Jung 2009; Jung 2011). In the broader context of globalization, indeed as argued by Jung and Li (2014: 2790), Gangnam Style was one of the most notable phenomena in the world of popular culture in 2012 and this was due to the dynamic interplay of traditional and new media outlets, the active participation of global audiences, the video's spreadable hook, a laissez-faire copyright policy, and Psy's marketing strategies. Jung and Li (2014: 2791) went on to argue that Gangnam Style facilitated the understanding of the circulation pattern of popular music content on YouTube and the complex relationships among audiences, celebrities, and mainstream media in the digital platforms.

With regards to the studies of news framing in the context of the studies about the Korean Wave, there is a wealth of literature including Yoon (2002), Shin (2005) and Yu et al. (2012). While Yoon (2002) considered the ways in which the Korean media reported the Korean wave in China, a comparative study was conducted by Shin (2005) using the sample of Korean Wave-related news in Chinese and Korean media. More recently, Yu et al. (2012) examined the prevalent news frames used in the Korean wave-related news in two major Chinese daily newspapers, People's Daily and Jinghua Daily. It was by employing deductive approach that the prevalent (dominant) news frames were identified (Yu et al. 2012). The most frequently used frame was cultural interest frame, followed by economic 
frame and policy frame (Yu et al. 2012: 202). Overall, the analysis of the news frames in cross-cultural context is thus considered an effective way of understanding how the Korean wave is conveyed by the local media and how it is interpreted and evaluated by the local audience.

A number of studies have used the news frame analysis in order to investigate the prevalence of the news frames and their implications (see Gitlin 1980; Entman 1993; Semetko and Valkenburg 2000; Tuchman 1978; Yu et al. 2012). According to Entman (1993: 51), the concept of framing offers a way to describe the power of a communicating text. He argued that "analysis of frames illustrates the precise way in which influence over a human consciousness is exerted by the transfer (or a communication) of information from one location - such as a speech, utterance, news report, or novel - to that consciousness" (Entman 1993: 51-52). Although there is no single definition of news frame or framing, many studies suggest that news frames are "conceptual tools which media and individuals rely on to convey, interpret and evaluate information" (Neuman et al. 1992: 60). News frames set the parameters "in which citizens discuss public events" (Tuchman 1978: iv) and these news frames are "persistent selection, emphasis and exclusion" (Gitlin 1980: 7). There thus seems a general consensus that the news media is involved in selecting "some aspects of a perceived reality" to enhance their salience (Entman 1993: 53) and the audience gets the mediated reality. News frames have been shown to have profound consequences for the public's interpretation of events and issues (lyengar 1991; Neuman et al. 1992). According to De Vreese (2005: 52), the consequences of framing can be conceived on the individual and the societal level. An individual level consequence may be altered attitudes about an issue based on exposure to certain frames. On the societal level, on the other hand, frames may contribute to shaping social level processes such as political socialization, decision-making, and collective actions (De Vreese 2005: 52).

Semetko and Valkenburg (2000) contended that a reliable set of content analytic indicators is necessary for studying developments in the news over time and similarities and differences in the ways in which politics and other topics of national and international importance are framed in the news in different countries. When it comes to content analyzing frames in the news, Semetko and Valkenburg (2000) provided one of the most useful frameworks. They put forward two possible approaches: inductive and deductive. The inductive approach involves analyzing a news story with an open view to attempt to reveal the array of possible frames, beginning with very loosely defined preconceptions of these frames (Semetko and Valkenburg 2000: 94). Whilst this approach can detect the many possible ways in which an issue can be framed, it is labor intensive, often based on small samples, and can be difficult to replicate. The deductive approach, on the other hand, involves predefining certain frames as content analytic variables to verify the extent to which these frames occur in the news (Semetko and Valkenburg 2000: 94). This approach can be replicated easily, can cope with large samples, and can easily detect differences in framing between media (for example, television vs. press) and within media (for example, highbrow news programs or newspapers vs. tabloid-style media). When working with a deductive approach, the relevant question is: what (which components) in a news story constitutes a frame (De Vreese 2005: 54). According to Entman (1993: 52), frames in the news can be examined and identified by 'the presence or absence of certain keywords, stock phrases, stereotyped images, sources of information and sentences that provide thematically reinforcing clusters of facts and judgments. This study has taken on board all of the above suggestions in terms of the research design and in particular, establishing the five news frames to apply to the sample (see Table 1.), as discussed in the next section

\section{Research design and methodology}

This study adopted the news frame analysis method. Two daily newspapers - Chosun Ilbo and Hankyoreh - have been selected and the sample was collected between $15^{\text {th }}$ July 2012 and $16^{\text {th }}$ March 2013. There are two things that need explaining here: first, what is the rationale behind the selection of the above two papers; and second, why the particular period for the sampling was chosen. As mentioned earlier, news media has the agenda setting role in society, which affects people's perception about certain issues. Chosun Ilbo and Hankyoreh are representative of a wide spectrum of different editorial approaches in the contemporary Korean press. While the first is known for its conservative standpoints, the latter is referred to as more liberal and progressive paper. The reason why this right-left opinion cleavage is important lies not in the newspaper-style tug of war between right and left but in the peculiarities of the news framing process. News framing in these papers, which 
are most influential and symbolic in both ends of the opinion spectrum, is most likely to affect policy making, especially in terms of the direction of the cultural contents production in the future.

D'Angelo (2002: 880) demonstrated that, as a response to Entman (1993), news framing has three subprocesses; a frame construction flow, a framing effects flow and a frame definition flow. Firstly, the frame construction flow represents a combination of frame building and frame setting and there are a variety of framing devices that carry news frames (Cappella and Jamieson 1997: 45). For example, Gitlin (1980) found the devices of trivialization, polarization, emphasis of internal dissention, marginalization and undercounting. Entman (1993) also defined news frames based on how issue or events are carried by framing devices that define problems, diagnose causes, make moral judgments, and suggest remedies. Secondly, the framing effects flow shows that what frames affect is mediated by intervening processes such as official discourses of government figures, political candidates, social movements, and prior knowledge underlying individuals' decision making and interpretations (D'Angelo 2002: 882). It is, therefore, not one-way process. Thirdly, the frame definition flow is about a recursive loop in the study of framing. The reason why such a right-left opinion cleavage is important is that, in all three subprocesses as mentioned above, Chosun llbo and Hankyoreh are most likely to show different framing devices that carry frames, and contrasting ways to recognize and investigate an individual- and social-level reality. As argued by D'Angelo $(2002,880)$ news frames interact with official discourse, audience frames and prior knowledge which consequently mediate effects on a number of areas on political, social and cognitive levels: for example, like public opinion, policy debates, social movement, voting and interpretations. For this reason, Chosun Ilbo and Hankyoreh were selected as one could anticipate some significant contrasts and also their effects on public opinion, policy debates and so forth would be most prominent. In addition, Chosun Ilbo is the leading newspaper in Korea, with circulations of 1,769,310 per day whilst Hankyoreh was also ranked at the eighth place (with circulations of 269,174 per day) in terms of circulations (Chosun Media 2013). The samples from each paper were, therefore, comparable on many grounds.

In order to elaborate this further, director Shim Hyung Rae's movie "D-War" (2007) provides an apt example. Both papers had employed similar title: "D-War Breaks Korean Box Office Record in U.S." (Chosun Ilbo, September 17, 2007) and "D-War Shoots to the Top" (Hankyoreh, August 7, 2007). Whilst the news stories were both about the box office success of this monster movie, Chosun Ilbo's approach was more factual and succinct and Hankyoreh emphasized the critique of the film, expanding the story to the Koreans' discontent over a cut in the screen quota system posed by the US film industry. Hankyoreh's coverage included another director - an independent filmmaker - Lee Song Hee-il's episode that how he was forced to shut down his blog because of its furious reception by "D-War" fans about his critical review of the movie. By contrast, Chosun Ilbo reported director Shim's press conference with his interview in details, supporting his preference and emphasis on commercial achievement - signing the contract with Sony Pictures for DVD and video distribution of the movie over artistic merits (Chosun Ilbo September 4, 2007). Here, a clear evidence of taking on different framing devices that carry news frames can be witnessed. Hankyoreh $\left(17^{\text {th }}\right.$ September, 2007) reported harsh reviews from critics such as the use of shallow humor and weak storyline, however, in the case of Chosun Ilbo, critical reception of the movie was largely trivialized and marginalized and instead the movie was promoted using a patriotic sentiment. Interestingly enough, a twist of the story is the fact that despite its promising start in the early stage, the movie has a huge loss in both domestic and US markets, followed by another disappointing box office sales by director Shim, "The Last Godfather (2010)", and eventually Shim's company Young Gu Art fell into heavy debts and bankruptcy (Korea Times, December $\left.18^{\text {th }}, 2011\right)$.

Now, the reason why a particular period was chosen needs justification. 35 weeks long sampling period started with the release of Gangnam Style on YouTube and finished with Psy's official announcement on Twitter about ending his promotional activities regarding Gangnam Style. Both timings were significant in terms of the development of Gangnam Style reception and fandom. This period was then further broken down to four interrelated but relatively distinctive moments: recognition, spread, peak and continuation period. It was in response to the lack of attention paid into different stages by the existing literature on Gangnam Style. As shown in Fisher (2012), Cho (2012), Lie (2013), and Jung and Li (2014), Gangnam Style craze was reflectively analyzed as relatively static phenomenon using holistic approaches. However, few studies examined different stages in the 
development of Gangnam Style fandom. This is the reason why the sampling period was broken down to four sub-periods of recognition, spread, peak and continuation in this study. The first stage of the sampling resulted in 697 articles from the Chosun Ilbo and 193 from Hankyoreh, all of which had the keyword - Gangnam Style - appearing at least once. However, there were stories which were remotely relevant to the actual song and therefore the sample was consequently narrowed down to 400 articles in total: 318 articles from the Chosun Ilbo and 82 from Hankyoreh.

News media can have different perspectives on the same issue or event depending on their own organizational interests, values and ideologies. By comparing the news frames used in reporting Gangnam Style in two different daily newspapers (one conservative and another progressive), this paper aims to compare and contrast the similarities and differences from each paper's sample in terms of the ways in which the news was framed, depending on the timing of the news and the type of the newspaper it appeared. Therefore, our research questions are as follows:

RQ 1: What are the similarities and differences in terms of the news framing in Chosun llbo and Hankyoreh about the reception of Gangnam Style, depending on the timing of the news and on the type of newspaper?

RQ 2: What is the most predominant frame used in the news stories about the reception of Gangnam Style, depending of the timing of the news and on the type of newspaper?

Semetko and Valkenburg's deductive approach was adopted to identify five news frames shown in the following table (Table 1.). To measure the extent to which certain frames appear in stories that mention the Korean wave, we derived the five dominant keywords in each news story and decided the most predominant frame.

Table 1: Five frames in the content analysis of news about the Korean wave

\begin{tabular}{ll}
\hline Framing items & Contents and keywords \\
Industry/economy & $\begin{array}{l}\text { The effect of the Korean wave on the given country's economy. } \\
\text { frame }\end{array}$ \\
Keywords: "product", "export", "import", "turnout", "promotion", "tourism", \\
"shares", "share prices" \\
frame \\
Emphasis on the popularity of the Korean wave and on the superiority of the \\
Korean culture. National pride as the nation that exports cultural contents. \\
Keywords: "invasion", "conquest", "capture", "occupation", "fever", "craze", \\
"sweep"
\end{tabular}

Source: Authors' table; categories adopted from Semetko and Valkenburg (2000)

The total of 35 -weeks-long period from $15^{\text {th }}$ July 2012 to $16^{\text {th }}$ March 2013 has been further broken down to the following four periods. Firstly, during the first 5 weeks, it is the period of recognition (the authors' emphasis) when the global media such as CNN, The Wall Street Journal, The Los Angeles Times, and The Time reported the issues around Gangnam Style. Second period (of spread or diffusion, expansion) starts with $6^{\text {th }}$ week and last another 5 weeks during which is marked with the rapid increase of YouTube views of Gangnam Style music video, coincided with Psy's promotion and performances in America. This is followed by the third period (of peak) from Week 10 to Week 13 when Gangnam Style recorded No. 2 in Billboard Chart, No. 1 in the British music chart, 300 million views on 
YouTube: in addition, this is when Psy started to perform more often for the domestic audiences, including the free concert at the Korean capital's City Hall Plaza. Lastly, the period from Week 14 to Week 35 is one of continuation which showed a consistent and stable level of media interests and coverage.

In terms of the coding procedure, three undergraduate mass communications students took part in the coding process and the intercoding reliability test was carried out in order to secure the reliability and validity of the research. Cohen's Kappa result was 0.91 which is at an acceptable standard.

\section{4. $\quad$ Findings and discussion}

The most commonly used method to control the news framing is by way of controlling the frequency. As shown below (Figure 1.), it is noticeable that there were higher frequencies during the weeks leading up to the third period - the peak period. As there were more news stories in foreign media, both Chosun Ilbo and Hankyoreh had the sources of the news story from foreign media. Chosun Ilbo overall had more stories on this issue than its counterpart.

The keywords and frequently recurring descriptions on the topic in each period were as follows:

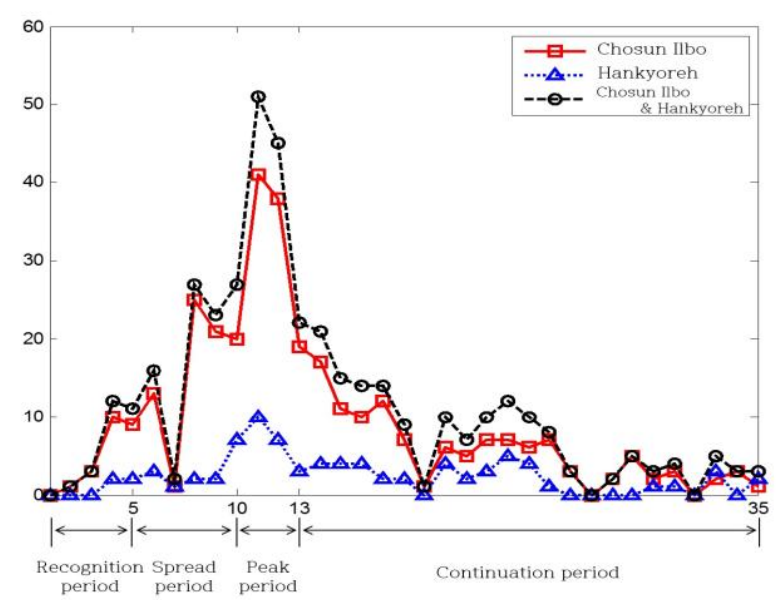

Figure 1: Frequency of the news stories about Gangnam Style; Source: Authors' findings

Table 2: Keywords and descriptions in Gangnam Style related news stories

\begin{tabular}{llll}
\hline & Period & Chosun llbo= & Hankyoreh \\
\hline Keywords & Recognition & He who shakes the whole nation with Strange name/singer Psy \\
and & period & Gangnam Style \\
descriptions & Spread & Psy, fluent in English, puts Korea on the Main trend/current/iconic figure \\
for Psy & period & map/Psy conquers the music charts in in the Korean wave cultural \\
& & Korea and then appears in America nationalism
\end{tabular}

Peak period Psy as the world class pop star/Psy's Most Korean singer/No. 1 in status as the worl class celebrity iTunes chart in

America/YouTube president Psy Continuation Conquering the world/Psy brings World mesmerized by Gangnam period Gangnam Style craze to the world/world Style/Psy shakes 2012 Korean star overnight popular music industry/Psy talked about in the global context

Keywords Recognition Other world start praise Psy/audience Toxicate the world beyond and period falling in love with Psy/Psy causes a Korea/world audience descriptions sensation/Foreign press also praise engaging/parody videos of for the Gangnam Style/Langnam Style landing in Gangnam Style appearing in global Europe beyond Japan and America many different countries/hot topic in Korea and abroad

reception

of Gangnam Spread

Style period

New Korean wave/Foreign media showing Unbelievable craze/attracting a great deal of interests in 'B-grade music the world/Psy's vulgar, 'B-grade video'/worldwide sensation/going beyond culture' as the catharsis for the the success of K-pop/Psy craze in the audiences' anxieties whole of America

Peak period 'Craze'/conquering the Billboard Global syndrome/worldwide chart/great opportunity to let the world phenomenon/unexpected hit know about Korea and superiority of the Korean music/Official No. 1 in the British 
chart/conquering the music charts in the

world/the whole world is Psy's

world/Gangnam Style winning the world

over

Continuation Unprecedented, phenomenal, global Social

period success/Conquering the YouTube/No. 1 phenomenon/transnational product of the year/Spirit of Zinghiskan , musical code key to the success conquering the world of Gangnam Style

Keywords Recognition None None

and period

descriptions Spread

for the period

implications

of Gangnam

Style's

success

Peak period

Special advertising effect/The world Gangnam Council trying to watching Gangnam with curiosity/New make most of Psy's phase for the tourism industry in popularity/Enough of the Korea/The richest man Yang Hyun Suk (YG Korean wave and nationalism Entertainment)

Economic value of Psy/Psy's success in What has Psy's No. 1 in the profitable markets/Brand value of Billboard chart got to do with Seoul/promotional effect the status of the worldwide/Korea Tourism Organization nation?/Entertainment

and Gangnam Council also focusing on companies' shares going 'Gangnam Style marketing'

up/Distorted, nationalistic imagination such as

"conquering the world"

Continuation Psy becomes much sought after in Need to give up the period American advertising market/Ending the nationalistic marketing thought and belief of American strategies relying on the domination of global culture/K-pop as an national pride/inappropriate excellent textbook for learning Korean and excessive gestures by the language/Psy and other Korean musicians media and the public, need to consider working the lyrics overemphasizing the effect of reflecting higher standard and class. this phenomenon.

Source: Authors findings

The above table illustrates that there was no significant difference in terms of the use of keywords and descriptions depending on different timing. There was a sense of consistency throughout the four periods. In addition, it was not significantly different either between the two papers. Psy was referred to as the 'world star' most frequently in both papers. However, there was a slight difference in terms of the ways in which each paper reported the global reception of Gangnam Style. Whilst Chosun Ilbo used such expressions as 'invasion', 'sweep', 'craze' and 'fever', rather calm and understated tone was clearly felt in Hankyoreh's stories. For example, the 'big issue' and 'engagement or symphathy' were used in the second period of spread in Hankyoreh and also their use of the term 'B grade culture' showed how the critics interpreted this song and its dance routine. Having said that, in the peak period both papers had overly heated and celebratory tone by using descriptions like 'fever' and 'global phenomenon'. It was during the last period when we could witness stark contrast between the two papers: Chosun Ilbo continued maximizing the impact of this phenomenon whereas Hankyoreh's stories tended to be more analytical, examining in a reserved manner the reasons behind Gangnam Style's success which was once described as 'coincidental'.

When it came to the impact and implications of Gangnam Style's success in the global context, there was a big difference: Chosun Ilbo consistently framed the stories from economic perspectives, using such words as 'economic impact of Psy', 'brand value' and 'profits'. On the other hand, more stories on Hankyoreh criticized the 'nationalistic marketing' while using expressions like 'disproportionately high emphasis and significance' given to this phenomenon.

Regarding the second research question (RQ2), the following table (Table 3.) shows that the most predominant frame used in Chosun Ilbo was globalization frame ( 50 per cent) whereas cultural 
interest frame (32 per cent) appeared most often in Hankyoreh sample. The second most frequently used frame was competition frame in both papers, merely reporting the recent events, achievements and records. For Chosun Ilbo's sample, it was followed by criticism frame and economy frame whereas criticism frame and globalization frame followed in Hankyoreh's sample. In particular, there were only two stories in Chosun Ilbo which used criticism frame. Similarly, economy frame only appeared 4 times in Hankyoreh.

Table 3: Dominant news frames used in gangnam style related stories $(\mathrm{N} / \%)$

\begin{tabular}{|c|c|c|c|c|c|c|c|c|c|}
\hline \multirow[t]{2}{*}{ Period } & \multicolumn{2}{|c|}{$\begin{array}{r}\text { Recognition } \\
\text { (Week 1- Week 5) }\end{array}$} & \multicolumn{2}{|r|}{$\begin{array}{r}\text { Spread } \\
\text { Neek 10) }\end{array}$} & \multicolumn{2}{|c|}{$\begin{array}{r}\text { Peak } \\
\text { (Week 11-Week 13) }\end{array}$} & \multicolumn{2}{|c|}{ (Week 14 - Week 35) } & otal \\
\hline & $\begin{array}{r}\text { Chosun } \\
\text { Ilbo }\end{array}$ & $\begin{array}{r}\text { Hankyo } \\
\text { Reh }\end{array}$ & $\begin{array}{r}\text { Chosun } \\
\text { Ilbo }\end{array}$ & $\begin{array}{r}\text { Hankyo } \\
\text { reh }\end{array}$ & $\begin{array}{r}\text { Chosun } \\
\text { Ilbo }\end{array}$ & $\begin{array}{r}\text { Hankyo } \\
\text { reh }\end{array}$ & $\begin{array}{r}\text { Chosun } \\
\text { Ilbo }\end{array}$ & $\begin{array}{r}\text { Hankyo } \\
\text { reh }\end{array}$ & \\
\hline $\begin{array}{l}\text { Industry/ } \\
\text { economy } \\
\text { frame }\end{array}$ & $\begin{array}{r}0 \\
(00.0)\end{array}$ & $\begin{array}{r}0 \\
(00.0)\end{array}$ & $\begin{array}{r}10 \\
(13.3)\end{array}$ & $\begin{array}{r}2 \\
(16.7)\end{array}$ & $\begin{array}{r}19 \\
(20.9)\end{array}$ & $\begin{array}{r}2 \\
(12.5)\end{array}$ & $\begin{array}{r}3 \\
(3,1)\end{array}$ & $\begin{array}{r}0 \\
(00.0)\end{array}$ & \\
\hline $\begin{array}{l}\text { Globalization } \\
\text { frame }\end{array}$ & $\begin{array}{r}13 \\
(68.4)\end{array}$ & $\begin{array}{r}0 \\
(00.0)\end{array}$ & $\begin{array}{r}42 \\
(54.7)\end{array}$ & $\begin{array}{r}0 \\
(00.0)\end{array}$ & $\begin{array}{r}32 \\
(35.2)\end{array}$ & $\begin{array}{r}4 \\
(25.0)\end{array}$ & $\begin{array}{r}54 \\
(55.1)\end{array}$ & $\begin{array}{r}8 \\
(21.6)\end{array}$ & 1 \\
\hline al & $\begin{array}{r}6 \\
(31.6)\end{array}$ & $\begin{array}{r}4 \\
(100)\end{array}$ & $\begin{array}{r}11 \\
(14.7)\end{array}$ & $\begin{array}{r}3 \\
(25.0)\end{array}$ & $\begin{array}{r}8 \\
(8.8)\end{array}$ & $\begin{array}{r}5 \\
(31.3)\end{array}$ & $\begin{array}{r}16 \\
(16.3)\end{array}$ & $\begin{array}{r}10 \\
(27.0)\end{array}$ & \\
\hline Critici & $\begin{array}{r}0 \\
(00.0)\end{array}$ & $\begin{array}{r}0 \\
(00.0)\end{array}$ & $\begin{array}{r}1 \\
(1.3)\end{array}$ & $\begin{array}{r}4 \\
(33.3)\end{array}$ & $\begin{array}{r}1 \\
(1.1)\end{array}$ & $\begin{array}{r}2 \\
(12.5)\end{array}$ & $\begin{array}{r}0 \\
(00.0)\end{array}$ & $\begin{array}{r}5 \\
(13.5)\end{array}$ & \\
\hline $\begin{array}{l}\text { Competition } \\
\text { Frame }\end{array}$ & $\begin{array}{r}0 \\
(00.0)\end{array}$ & $\begin{array}{r}0 \\
(00.0)\end{array}$ & $\begin{array}{r}12 \\
(16.0)\end{array}$ & $\begin{array}{r}3 \\
(25.0)\end{array}$ & $\begin{array}{r}31 \\
(34.1)\end{array}$ & $\begin{array}{r}3 \\
(18.8)\end{array}$ & $\begin{array}{r}25 \\
(25.5)\end{array}$ & $\begin{array}{r}14 \\
(37.8)\end{array}$ & 8 \\
\hline Total & $\begin{array}{r}19 \\
(100)\end{array}$ & $\begin{array}{r}4 \\
(100)\end{array}$ & $\begin{array}{r}75 \\
(100)\end{array}$ & $\begin{array}{r}12 \\
(100)\end{array}$ & $\begin{array}{r}91 \\
(100)\end{array}$ & $\begin{array}{r}16 \\
(100)\end{array}$ & $\begin{array}{r}98 \\
(100)\end{array}$ & $\begin{array}{r}37 \\
(100)\end{array}$ & \\
\hline
\end{tabular}

Source: Authors' findings

In terms of the correlation between the timing of the news and its predominant frame, during the first period of recognition, globalization frame was most frequently used in Chosum Ilbo whilst this way of framing was not even once used in Hankyoreh and instead cultural interest frame dominated. Most stories in Chosun Ilbo during this period quoted the American media such as CNN, The Wall Street Journal, The Time as its main source of the news, transpiring the sense of Gangnam Style's invasion to the American market. By contrast, Hankyoreh's stories tend to analyze the reasons why this song became popular from cultural perspectives. During the second period of spread and diffusion, there was a greater degree of diversity in terms of the news frames. However, in Chosun Ilbo more than half the stories used globalization frame, same as the previous period. The majority of the news stories dealt with how Psy made appearances in American television and heavily focused on a number of the western celebrities, for example, Tom Cruise, Ellen DeGenere, and Katy Perry who talked about Psy and his music. In addition, more stories were found to have used economy frame' and competition frame in Chosun Ilbo in comparison to the previous period. On the other hand, criticism frame was most frequently used in Hankyoreh, most of which had a cautious attitude towards overly nationalistic media euphoria. Interestingly enough, it was from this period that Hankyoreh also took some economy frame in their reporting.

During the peak period, both papers had highest number of stories, with a rapid increase throughout. Globalization frame and economy frame were the two most frequently used frames in the stories covering everything from Psy's fashion, dance, to humor. Hankyoreh's stories, however, were more in-depth and analytical, highlighting the fact that there are darker sides of K-pop. They drew people's attention to more serious issues like the fundamentals of Psy's success in western popular culture, how best to improve the overall perception of K-pop, and the urgent need to overcome nationalistic attitude in both media and general public.

\section{Conclusion}

The success of Gangnam Style is a good example of how once 'the periphery' (Shim 2006; Ryoo 2009) could find a subversive way into the mainstream western popular music industry using social 
media. This brought a great deal of media attention in both domestic and global contexts. This study examined the predominant frames used in the news stories about Gangnam Style in Chosun Ilbo and Hankyoreh. Both papers carried considerably larger amount of articles on this topic compared to any other stories about popular culture, which highlights the importance of this issue to the public. Chosun Ilbo, in particular, has four times more stories than Hankyoreh. Both papers shared the tendency of emphasizing the success of Gangnam Style worldwide but they showed a clear difference in terms of how they analyzed the possible cause and effect of this phenomenon. Chosun Ilbo used globalization frame most frequently to propose and reinforce the status of Korea as the prominent exporter of cultural contents. By contrast, cultural interest frame was most often used in Hankyoreh which at the same time criticized the nationalistic marketing approach that linked the success of Gangnam Style to the national achievements. Thus, another frequently used frame was criticism frame which cautiously avoided an overly celebratory and nationalistic attitude. Another difference between the two papers lied in the use of economy frame. Whilst this frame appeared consistently throughout the sampling period in Chosun Ilbo, it was only during the peak period that Hankyoreh adopted this framing strategy. These findings were in line with the existing brand values and identities for each paper: that is to say, Chosun Ilbo is known as one of the most conservative papers in Korea, claiming to stand for and support the ethos of nationalism and progress. Hankyoreh, on the other hand, is regarded as a left-wing and progressive paper, strongly believing in individualism, equality and distribution.

It was noticeable that globalization frame and cultural interest frame were prevalent in Gangnam Style related news stories in comparison to the predominant theme of economy and industry frame in the so-called '1.0 Korean Wave' discourses in the past. This seems that culture oriented frames were formulated and most frequently used as they provided the media an analytical framework to explain why Gangnam Style was more popular in America and Europe rather than East Asia. However, unfortunately most stories were limited to descriptive account of the chart related information and news rather than being expanded to critical appraisal and analysis of the reception and consumption process and future prospects of the K-pop as a global cultural phenomenon. As a result, both papers failed to provide the public with the parameters in which Gangnam Style can be discussed in a broader context of the new Korean Wave.

In conclusion, Chosun Ilbo and Hankyoreh both acknowledged that Gangnam Style was an epochal event but their perspectives and news frames were different in terms of how they understood the reason behind its success and the implications. As Tuchman (1978: iv) suggested, news frames set the parameters "in which citizens discuss public events" and these news frames are, in Gitlin's (1980: 7) terms, "persistent selection, emphasis and exclusion". It is important to remember the fact that this provided a greater degree of diversity in public debates as well as private consumption of this cultural content. However, both papers focused on the celebration of how popular and superior the Korean popular culture became from a short term perspective rather than systematically and rigorously investigating a long term prospects and strategy to sustain the popularity of the 'new Korean wave' ('the 2.0 Korean wave'). In particular, Chosun Ilbo, which showed significantly higher frequencies of Gangnam Style related stories than its counterpart, has consistently identified the global popularity of Gangnam Style with the success and superiority of the Korean culture and the Korea as a nation. In order to facilitate more long term sustainability of the 'new Korean wave', merely nationalistic viewpoints and stories only emphasizing the economic impact need to be replaced by more critically analytical, reflective, in-depth stories from diverse perspectives.

Limitation of this study is that it only used the deductive approach in the sense that it started analyzing the news stories with the predefined frames as content analytic variables. This, however, could be the strength of this study as this method is easily replicable and it can also easily applicable to large sample. An ethnographic approach such as participant observation, focus group and in-depth interview could provide a useful direction for future research, adding a qualitative measure to the research.

\section{References}

BBC News. (2014). Gangnam video first to hit two billion views on YouTube. $31^{\text {st }}$ May 2014. Cappella, J. N. \& Jamieson, K. H. (1997). The Spirit of Cynicism: The Press and the Public Good. New York: Oxford University Press. 
Cho, W. S. (2012). Riding the Korean Wave From 'Gangnam Style’ to Global Recognition. Global Asia. 7(3), 35-39.

Choi, J. and Ryoo, W. (2012) Discourse Politics on the New Korean Wave - Focusing on the Discourse Analysis of the Major Korean Newspapers' Articles. Korea Dance Studies. 19, 345-378.

Chosun Media. (2013). Chosun Ilbo Media Guide: Korea ABC Daily Newspaper Circulations Report. Seoul. November.

Chosun Ilbo. (2007). D-War Breaks Korean Box Office Record in U.S. $17^{\text {th }}$ September 2007. Retrieved from: http: engligh.chosun.com/site/data/html_dir/2007/09/17/2007091761013.html [Accessed on 21st January 2015]

Chosun Ilbo. (2007). D-War Director Returns Home Triumphant. $4^{\text {th }}$ September 2007. Retrieved from: http: english.chosun.com/site/data/html_dir/2007/09/04/2007090461018.html [Accessed on 21 ${ }^{\text {st }}$ January 2015]

D’Angelo, P. (2002). News Framing as a Multipatadigmatic Research Program: A Response to Entman. Journal of Communication, December, 870-888.

De Vreese, C. H. (2005). News framing: Theory and typology. Information Design + Document esign, 13(1), 51-62.

Entman, R. M. (1993). Framing: Toward clarification of a fractured paradigm". Journal of Communication. 43(4), 51-58.

Fisher, M. (2012). Gangnam Style, Dissected: The Subversive Message within South Korea's Music Video Sensation. The Atlantic.

Gitlin, T. (1980). The whole world is watching: Mass media in the making and unmaking of the New Left. Berkeley: University of California Press.

Hankyoreh. (2007). D-War shoots to the top. $7^{\text {th }}$ August 2007. Retrieved from: http: english.hani.co.kr/arti/english_edition/e_entertainment/227414.html [Accessed on 21st January 2015]

lyengar, S. (1991). Television news and citizens' explanations of national affairs. American Political Science Review, 81, 815-831.

Jung, S. Y. (2009). A Study on the significance of the Korean wave and prospects for the relationship between Korea and Japan: Focus on Japanese women audience". Media, Gender \& Culture, 11, 75122.

Jung, S. Y. (2011). A study on Exploring for Hallyu Landscape and Cultural Practice of Audiences in Japan. Media, Gender \& Culture, 20, 207-239.

Jung, S \& Li, H. (2014). Global Production, Circulation, and Consumption of Gangnam Style. International Journal of Communication [Online]. 8, 2790-2810.

KBS. (2012). Korean Press to look only Billboard". Media Inside. $2^{\text {nd }}$ November 2012.

Ko, K. S. (2012). Korean Newspapers' Coverage of Gangnam Style. Kwanhun Journal, 125, 88-94.

Kim, Y. C., Lee, D. H. \& Lee, G. H. (2005). "A Study on Political and Cultural Implications of Korean Wave Media Contents. Korean society for journalism and communication studies research report, 53-80.

Lie, J. (2013). Why Didn't Gangnam Style Go Viral in Japan?: Gender Divide and Subcultural Heterogeneity in Contemporary Japan. Cross-Current: East Asian History and Culture Review, 9, December.

Neuman, R. W., Marrion R. J. \& Crigler, A. N. (1992). Common Knowledge. Chicago: University of Chicago Press.

Ryoo, W. J. (2009). Globalization, or the logic of cultural hybridization: The case of the Korean wave. Asian Journal of Communication, 19(2), 137-151.

Semetko, H. A. \& Valkenburg, P. M. (2000). Framing European politics: A content analysis of press and television news. Journal of Communication, 50(2), 93-109.

Shim, D. B. (2006). Hybridity and the rise of Korean popular culture. Media, Culture and Society, 8(1), 2544.

Shin, H. J. (2005). The cultural politics of 'K-pop' in the era of transregional cultural traffics. Media \& Society, 13(3), 7-36.

The Korea Times. (2011). Employees of ex-comedian win suit over unpaid wages. $18^{\text {th }}$ December 2011.

Tuchman, G. (1978). Making News: A Study in the Construction of Reality. New York: Free Press 
Yoon, T. J. (2002). Korean newspaper' coverage of Hallyu in China. Korean Journal of Broadcasting and Telecommunication Studies, 20(3), 78-107.

Yu, S. K., Lee, S. \& Chung, J. I. (2012). Analysis of the "Korean Wave" news frame of Chinese daily newspapers: Based on the analysis of articles reported between 2001 and 2010. Journal of Communication \& Information, 57, 202-226. 